\title{
Technology Acceptance of e-Commerce Based on Smartphone Application on MSMEs in Grobogan and Jepara
}

\author{
Andi Wijayanto ${ }^{1}$, Agus Hermani D. Seno ${ }^{2}$ \\ \{andiwijayanto@lecturer.undip.ac.id ${ }^{1}$ \} \\ Universitas Diponegoro, Indonesia ${ }^{1,2}$
}

\begin{abstract}
Indonesia is one of the countries with the highest e-commerce growth rates in the world. However, the use of e-commerce applications, especially based on android smartphones by MSMEs is still lacking. This study aims to prove the effect of perceived ease of use and perceived usefulness on attitude toward using and behavioral intention to use on MSMEs in Grobogan and Jepara Regencies toward using smartphones. The study population is all MSMEs that are guided by the Industry and Trade Office of Central Java Province in Grobogan and Jepara Regencies. The research sample was taken by purposive sampling. Data collection methods using questionnaire, interview, observation and documentation. The measurement scale uses a Likert scale. Data analysis techniques include descriptive and inferential analysis using linear regression analysis. The results showed that perceived ease of use was not significant as a predictor of perceived usefulness; Perceived ease of use has a positive and significant effect on attitude toward using; perceived usefulness has a positive and significant effect on attitude toward using; perceived usefulness has no significant effect on behavioral intention to use; attitude toward using has positive and significant effect on behavioral intention to use.
\end{abstract}

Keywords: Perceived Ease of Use; Perceived Usefulness; Attitude toward Using; Behavioral Intention to Use.

\section{Introduction}

Information and communication technology have developed very rapidly. The increasingly inexpensive information technology devices supported by better, more extensive and affordable internet networks have changed the way many people do things in life. One phenomenon in the business sector that is growing rapidly with the support of information technology is the extraordinary growth of e-commerce. E-commerce is the activity of distributing, buying, selling, marketing goods and services through an electronic system [1].

Indonesia is one of the countries with the highest e-commerce growth rates in the world. This is indicated by the increasing number of business people who develop their businesses on digital platforms. This was driven by the increasingly rapid information technology, especially smartphones that are supported by increasingly affordable internet access. Data shows that 73 percent of internet users in Indonesia access the internet through mobile devices and will continue to grow in the next five years (berinovasi.com).

The development of e-commerce should be utilized by micro, small and medium enterprises (MSMEs) in Indonesia to develop their businesses. The potential for developing 
MSMEs through e-commerce is very possible because of the advantages of e-commerce compared to conventional business models. Among the advantages are that it can save time and travel costs, find raw materials or products faster, open all the time, make shopping easier and lower costs that support efficiency. E-commerce also allows business people to be able to expand their markets easily and cheaply [2].

Although e-commerce has great benefits for the development of MSMEs, the use of ecommerce applications, especially based on Android smartphones by MSMEs is still lacking [3]. Various previous studies in Indonesia also showed that the average SME actors have not adopted e-commerce optimally [1][2]. Some of the factors causing the low adoption of ecommerce include the lack of knowledge and ability to use smartphone devices to carry out ecommerce in support of business development.

A person's behavior in using technology is explained by several theories, especially those that highlight how individuals are willing to accept and have the intention to use the technology. One theory that is widely used to explain this phenomenon is the Technology Acceptance Model (TAM). TAM was adapted from Theory of Reasoned Action (TRA) which has roots in psychological theory in the field of information systems. TAM was first formulated by Davis in 1985 [6]. TAM believes that the perceived usefulness and perceived ease of use will determine the individual's intention to use a system and become a mediator of actual system use.

The purpose of this study is to prove the effect of perceived ease of use on perceived usefulness and attitude toward using; perceived usefulness on attitude toward using and behavioral intention to use; and attitude toward using on behavioral intention to use.

\section{Theoretical Review}

\subsection{E-commerce}

E-commerce or electronic commerce is an activity of trading or buying and selling goods/services, or the transmission of funds or data through electronic networks, especially the internet [7].

The types of e-commerce continue to grow and very varied variations from time to time. Rebecca [7] mentions that there are at least seven basic forms of e-commerce namely Business-to-Business (B2B), Business-to-Consumer (B2C), Consumer-to-Consumer (C2C), Consumer-to-Business (C2B), Business-to-Administration (B2A), Consumer-toAdministration (C2A), and Online-to-Offline (O2O).

\subsection{Technology Acceptance Model (TAM)}

A person's behavior in using technology is explained by several theories, especially those that highlight how individuals are willing to accept and have the intention to use the technology. One theory that is widely used to explain this phenomenon is the Technology Acceptance Model (TAM). TAM was adapted from Theory of Reasoned Action (TRA) which has roots in psychological theory in the field of information systems. TAM was first formulated by Davis in [6] through his dissertation and a journal article [6]. 


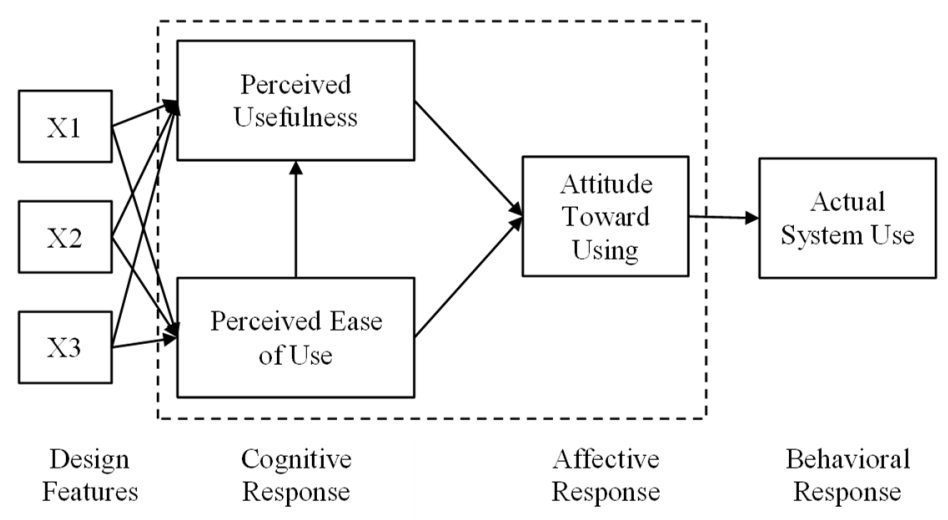

Fig. 1. Technology Acceptance Model (TAM) [6].

TAM believes that the perceived usefulness (PU) and perceived ease of use (PEU) will determine an individual's attitude to use (ATU) a system and become a mediator of actual system use. The TAM model is shown in Figure 1.

The model was then developed by Davis, et al. [8] by adding behavioral intention to use (BITU) after attitude toward using and before behavioral intention to use. The TAM model is shown in Figure 2.

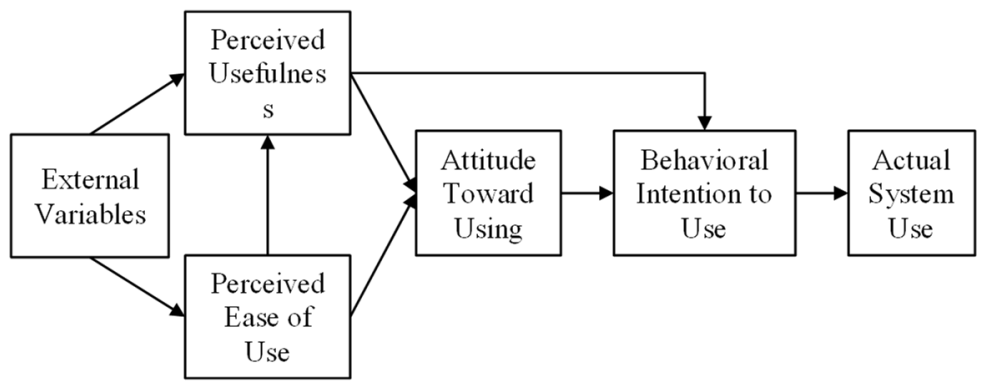

Fig. 2. Technology Acceptance Model (TAM) [8].

Figure 2 shows that the ATU of information technology is a function of PU and PEU. According to Davis [9] PEU will affect PU. This is because the easier the use of an information technology, the greater the benefits that will be felt by users [10]. PU is defined as the extent to which a person believes that using a particular system will improve the performance of his work. PEU is defined as the extent to which a person believes that using a particular system will be free of physical and mental effort [6]. ATU is defined as an individual's negative or positive feelings (evaluative feelings) towards the implementation of certain behaviors [11]. BITU is defined as the subjective probability of individuals to perform certain behaviors, especially in using information systems [11].

Figure 2 also shows that PU can directly influence BITU. Davis et al. [8] explained that in general people will arise the intention to behave after feeling the feeling of affection for a particular object. But the facts also show that there are people where perceptions of benefits can foster behavioral intentions without the need for affection first. In organizational settings, people grow intentions to behave because they believe that the use of certain technologies will 
improve their performance, even if they like or dislike the technology. This is because an increase in their performance will have an impact on the various rewards they will receive, or an increase in the profits they will get.

Based on a theoretical study, the research hypothesis was formulated as follows:

H1: PEU has a significant effect on PU

H2: PEU has a significant effect on ATU

H3: PU has a significant effect on ATU

H4: PU has a significant effect on BITU

H5: ATU has a significant effect on BITU

The research hypothesis can be described as a model as follows:

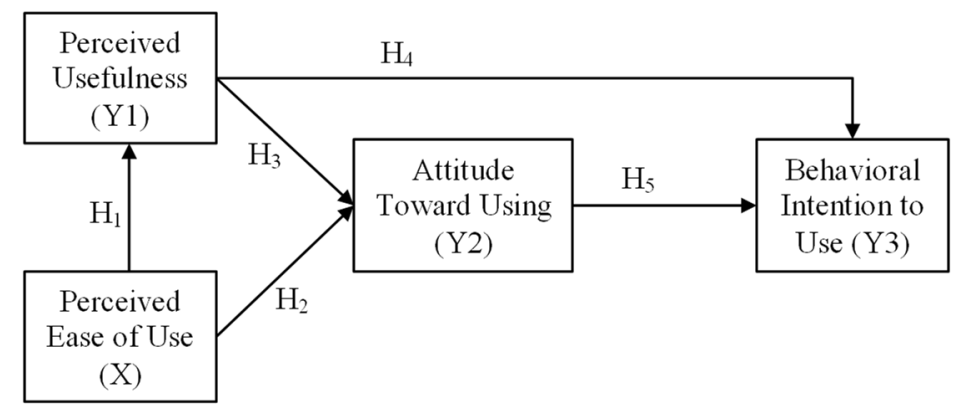

Fig. 3. Hypothesis Model.

\section{Method}

The PEU variable is measured by ease of how to register, ease of learning, and ease of use. PU is measured by benefits in increasing business effectiveness, useful in facilitating obtaining raw materials, improving business performance, reducing business operating costs. ATU is measured by can accept e-commerce applications, and the feeling of pleasure using ecommerce applications. BITU is measured by willingness to use and desire to use it more often in the future.

The population of the study is all MSMEs that are guided by the Industry and Trade Office of Central Java Province in Grobogan and Jepara Regencies. The number of MSME entrepreneurs in Grobogan and Jepara Regency who received a training program from the Central Java Province Industry and Trade Office in 2019 was 60 people. The research sample was taken by census. Data collecting using questionnaires, interviews, observation and documentation. The measurement scale uses a Likert scale. Data analyzed using linear regression analysis.

\section{Result and Discussion}

Description of the average score of questionnaire items and variables is shown in Table 1. Based on the average score of the PEU variable is only 2.7133 . This shows that the level of 
ease of use of e-commerce applications according to the average respondent is low. MSMEs in Grobogan and Jepara have an average difficulty in using e-commerce marketplace applications.

Table 1. The average score of Indicator and Variable

\begin{tabular}{|l|c|c|c|}
\hline \multirow{2}{*}{ Variable } & \multirow{2}{*}{ Indicator } & \multicolumn{2}{|c|}{ Mean } \\
\cline { 2 - 3 } & & Indicator & Variable \\
\hline \multirow{3}{*}{ Perceived Ease of Use } & $\mathrm{X} 1.1$ & 2,7600 & \multirow{3}{*}{2,7133} \\
\cline { 2 - 3 } & $\mathrm{X} 1.2$ & 2,7872 & \\
\cline { 2 - 3 } & $\mathrm{X} 1.3$ & 2,7111 & \\
\hline \multirow{3}{*}{ Perceive Usefulness } & $\mathrm{X} 2.1$ & 1,7234 & \multirow{3}{*}{2,0608} \\
\cline { 2 - 3 } & $\mathrm{X} 2.2$ & 2,1818 & \\
\cline { 2 - 3 } & $\mathrm{X} 2.3$ & 1,8478 & \multirow{2}{*}{1,9457} \\
\cline { 2 - 3 } & $\mathrm{X} 2.4$ & 2,5000 & \multirow{2}{*}{1,6304} \\
\hline \multirow{2}{*}{ Attitude Toward Using } & $\mathrm{X} 3.1$ & 1,8478 & 1,6087 \\
\hline \multirow{2}{*}{ Intention to Use } & $\mathrm{X} 3.2$ & 2,0667 & \\
\cline { 2 - 3 } & $\mathrm{Y} 1$ & 1,6444 & \\
\cline { 2 - 3 } & $\mathrm{Y} 2$ & & \\
\hline
\end{tabular}

Source: Data Analysis Output (2019).

The average score of the PU is only 2.06. This shows that the benefits of using ecommerce applications according to the average respondent are low. MSMEs on average experience difficulties in using e-commerce marketplace applications so that they are less able to explore the benefits obtained. All aspects of PU were rated low or even very low by respondents.

The average score of the ATU is only 1.94. This shows that the average attitude of respondents towards e-commerce applications is low. MSMEs on average cannot yet accept or even like e-commerce marketplace applications. All aspects of ATU are rated low or even very low by respondents.

The average score of the BITU is only 1.63. This shows that the average attitude of respondents towards the desire to use e-commerce applications is very low. Although the use of smartphones has been widespread among SMEs, but their desire is not yet apparent to use them to support the businesses they manage. All aspects of BITU are rated low or even very low by respondents.

The results of data analysis to test the hypothesis are shown in table 2 . The variable PEU has no significant effect on PU, but has a significant effect on ATU. The variable PU has a positive and significant effect on ATU, but it is not significant on BITU. ATU significantly influences BITU.

Table 2. Hypothesis Testing

\begin{tabular}{|c|c|c|c|c|c|c|}
\hline $\mathbf{H}$ & Path & B & $\mathbf{t}$ & Sig. & $\mathbf{R}^{\mathbf{2}}$ & Decision \\
\hline $\mathrm{H}_{1}$ & $\mathrm{PEU} \rightarrow \mathrm{PU}$ & $-0,034$ & $-0,474$ & 0,637 & 0,070 & Rejected \\
\hline $\mathrm{H}_{2}$ & PEU $\rightarrow$ ATU & 0,225 & 3,094 & 0,003 & 0,423 & Accepted \\
\hline $\mathrm{H}_{3}$ & $\mathrm{PU} \rightarrow \mathrm{ATU}$ & 0,359 & 2,397 & 0,021 & 0,340 & Accepted \\
\hline $\mathrm{H}_{4}$ & $\mathrm{PU} \rightarrow \mathrm{BITU}$ & $-0,017$ & $-0,119$ & 0,906 & 0,018 & Rejected \\
\hline $\mathrm{H}_{5}$ & ATU $\rightarrow$ BITU & 0,434 & 3,598 & 0,001 & 0,477 & Accepted \\
\hline
\end{tabular}

The results of data analysis prove that the PEU does not significantly influence the PU. This means that the perception of ease of use of e-commerce marketplace applications does 
not affect the perception of the usefulness or benefits of using e-commerce marketplace applications. Some micro businesses in Jepara and Grobogan feel that although its use is relatively easy, it has not yet had a significant impact on improving their businesses. On the contrary, the majority of micro businesses in Jepara and Grobogan perceive the use of ecommerce marketplace applications is quite difficult even though they feel that the use of ecommerce marketplace applications will have a good impact on their business progress.

This finding does not support the TAM theory [6], [10]. TAM as stated by Davis [9] states that the PEU will affect the PU. This is because the easier the use of an information technology, the greater the benefits that will be felt by users [10]. The SMEs in Jepara and Grobogan feel that the use of e-commerce marketplace applications is difficult. However, they admit that as far as they know, the use of e-commerce marketplace applications is very beneficial for the development or performance of their business. This is caused by several factors, first, the average ability to use smartphone technology is low. This is related to the low level of education. Second, the age of the SMEs in Jepara and Grobogan is mostly from old age (53.06\% aged 40 years old or more) so that it affects their ability to learn (see Figure 2).

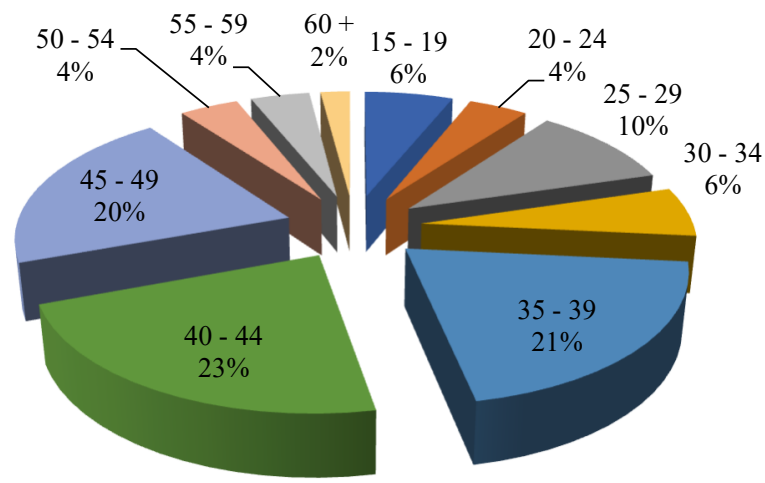

Fig. 4. Characteristic of Respondents by Age.

This finding supports the results of research by Agustian \& Syafari [4]. The findings of this study do not support the results of research by Davis [9], Widiana, Supit, \& Hartini's [12].

PEU is proven to have a positive and significant effect on attitude toward using. When micro businesses in Jepara Regency and Grobogan Regency assess the use of e-commerce marketplace applications is easy, it will cause feelings of joy or pleasure in using e-commerce marketplace applications. The contribution of the PEU variable to ATU is shown through R Square which is 42.3 percent, while 57.7 percent is influenced by other variables.

These results support the TAM theory [6]. This finding also supports the results of research conducted by Sidharta \& Sidh [13] which found that PEU has a significant effect on ATU. This finding does not support the research by Agustian \& Syafari [4] which found that PEU did not significantly influence ATU the internet in small and medium-sized businesses in South Sumatra.

PU has a positive and significant effect on ATU. When micro businesses in Jepara and Grobogan assess the use of e-commerce marketplace applications to bring benefits to them, it 
will cause feelings of joy or pleasure in using the e-commerce marketplace applications. The contribution of PU to ATU is 34 percent, while 66 percent is influenced by other variables.

These results support the TAM theory Davis [4] [6] which states that PU influences ATU. This means that the perception of the benefits of a technology can encourage the growth of affection towards MSMEs in Jepara and Grobogan to use e-commerce marketplace applications. Respondents considered that using e-commerce marketplace applications would be able to improve the marketing performance of their products so that they felt like or happy about e-commerce marketplace applications. This finding also supports the results of previous research conducted by Sidharta \& Sidh [13]. The results of his research found that PU has a significant effect on ATU.

PU has no significant effect on BITU. This means that the perception of the benefits of ecommerce marketplace applications does not affect the desire to use e-commerce marketplace applications. This result does not support Davis's [6], [9] theory. This means that cognitive aspects alone are not enough to directly encourage the growth of the desire of SMEs to use ecommerce marketplace applications. The rationality of respondents that using e-commerce marketplace applications can improve the marketing performance of their products is not enough to foster a desire to use e-commerce marketplace applications. This means that there must be an affection for e-commerce marketplace applications to be able to foster a desire to use e-commerce marketplace applications. This finding also does not support the results of research conducted by Sidharta \& Sidh [13]; Aisyah, et al. [14]; and Salamah, et al. [3].

This finding supports the results of research conducted by Agustian \& Syafari [4]. The results of his research found that PU does not affect BITU the internet in small and mediumsized businesses in South Sumatra.

ATU is proven to have a positive and significant effect on BITU. The more positive the attitude of the SMEs to the use of e-commerce marketplace applications, the higher their desire to use e-commerce marketplace applications. This means that when micro entrepreneurs in Jepara and Grobogan regencies emerge feeling like or happy about the use of e-commerce marketplace applications, it will foster their desire to use e-commerce marketplace applications. The contribution of ATU BITU is 47.7 percent, while 52.3 percent is influenced by other variables.

The findings support the results of research conducted by Sidharta \& Sidh [13] which found that ATU had a significant effect on BITU online shopping among STMIK students in Bandung. This finding does not support the results of research conducted by Agustian \& Syafari [4]. The results of his study found that ATU had no effect on BITU the internet in small and medium-sized businesses in South Sumatra.

\section{Conclusions}

PEU has no significant effect on PU. The conclusion of this study is different from the TAM theory [6][10]. This conclusion supports the results of Agustian \& Syafari's research [4], but does not support the results of the research of Davis [9], and Widiana, Supit, \& Hartini [12]. PEU has a positive and significant effect on ATU. These results do not support the theory of TAM which states that PEU affects ATU [6]. These findings support the results of research Sidharta \& Sidh [13]; but does not support the results of research Agustian \& Syafari [4]. PU has a positive and significant effect on ATU. This conclusion supports TAM [6][9]. This conclusion supports the results of Sidharta \& Sidh's research [13]. PU has no significant 
effect on BITU. These results do not support the TAM theory [6][9]. The results of this study do not support the research results of Davis, et al. [8], Sidharta \& Sidh [13], Aisyah, et al. [14], and Salamah, et al. [3]. This finding supports the results of research conducted by Agustian \& Syafari [4]. ATU positive and significant effect on BITU. The findings of this study support the research results of Sidharta \& Sidh [13], but do not support the results of research by Agustian \& Syafari [4].

The research suggests to increase the ability of MSMEs to adopt smartphone applicationbased e-commerce technology. In general, trainees after attending the training continued to have difficulty in using e-commerce applications on smartphones to improve their business performance. Real simulations and assistance to MSMEs are needed. Developers of ecommerce marketplace applications must be able to create a platform where e-commerce activities are fun activities, including for SMEs where the average level of their education is relatively low. Further research can examine the mediating effect of ATU variables on the relationship between PEU and PU on BITU.

\section{References}

[1] A. Anggraini, "E-commerce di Indonesia dan Perkembangannya," 2016. [Online]. Available: https://sis.binus.ac.id/ 2016 / $10 / 24$ / e-commerce - di - indonesia - dan -perkembangannya. [Accessed: 06-Mar-2019].

[2] P. B. Widagdo, "Perkembangan Electronic Commerce (E-commerce) di Indonesia," 2016. [Online]. Available: https://www.researchgate.net/publication/311650384_Perkembangan_ Electronic_Commerce_E-commerce_di_Indonesia. [Accessed: 06-Mar-2019].

[3] I. Salamah, A. Aryanti, L. Lindawati, and A. Asriyadi, "Model Penerimaan Teknologi ECommerce UMKM Kain Tenun Songket Kota Palembang," in Annual Research Seminar (ARS), 2017, vol. 3, no. 1, pp. 109-114.

[4] W. Agustian and R. Syafari, "Pendekatan technology acceptance model (TAM) untuk mengidentifikasi pemanfaatan internet usaha kecil dan menengah Sumatera Selatan," Semantik, vol. 4, no. 1, 2014.

[5] F. Wahid and L. Iswari, "Adopsi teknologi informasi oleh usaha kecil dan menengah di Indonesia," in Seminar Nasional Aplikasi Teknologi Informasi (SNATI), 2007.

[6] F. D. Davis, "A technology acceptance model for empirically testing new end-user information systems: Theory and results." Massachusetts Institute of Technology, 1985.

[7] Rebecca, "Jenis-Jenis E-commerce \& Contohnya," 2016. [Online]. Available: https://www.progresstech.co.id/ blog/jenis-e-commerce. [Accessed: 06-Mar-2019].

[8] F. D. Davis, R. P. Bagozzi, and P. R. Warshaw, "User acceptance of computer technology: a comparison of two theoretical models," Manage. Sci., vol. 35, no. 8, pp. 982-1003, 1989.

[9] F. D. Davis, "Perceived usefulness, perceived ease of use, and user acceptance of information technology," MIS Q., pp. 319-340, 1989.

[10] V. Venkatesh, "Determinants of perceived ease of use: Integrating control, intrinsic motivation, and emotion into the technology acceptance model," Inf. Syst. Res., vol. 11, no. 4, pp. 342-365, 2000.

[11] M. Fishbein and I. Ajzen, "Belief, attitude, intention, and behavior: An introduction to theory and research," 1977.

[12] M. E. Widiana, H. Supit, and S. Hartini, "Penggunaan teknologi internet dalam sistem penjualan online untuk meningkatkan kepuasan dan pembelian berulang produk batik pada usaha kecil dan menengah di Jawa Timur,” J. Manaj. dan kewirausahaan, vol. 14, no. 1, pp. 72-82, 2012.

[13] I. Sidharta and R. Sidh, "Pengukuran persepsi manfaat dan persepsi kemudahan terhadap sikap serta dampaknya atas penggunaan ulang online shopphing pada e-commerce," J. Comput. Bisnis, vol. 8, no. 2, pp. 92-100, 2014. 
[14] M. N. Aisyah, M. A. Nugroho, and E. M. Sagoro, "Pengaruh Technology Readiness Terhadap Penerimaan Teknologi Komputer Pada UMKM Di Yogyakarta,” J. Econ., vol. 10, no. 2, pp. 105-119, 2014. 